УДК 54.062:661.185

DOI https://doi.org/10.32838/TNU-2663-5941/2020.3-2/04

\title{
Пилипенко Т.М.
}

Національний технічний університет України

«Київський політехнічний інститут імені Ігоря Сікорського»

\section{Сфімова В.Г.}

Національний технічний університет України

«Київський політехнічний інститут імені Ігоря Сікорського»

Кузьменко А.Б.

Національний технічний університет України

«Київський політехнічний інститут імені Ігоря Сікорського»

\section{ПОРІВНЯЛЬНА ХАРАКТЕРИСТИКА ТА ОЦНЮВАННЯ ЯКОСТІ ДЕЗОДОРУЮЧИХ КОСМЕТИЧНИХ ПРОДУКТІВ}

Дезодоруючі косметичні продукти, антиперспіранти - ие косметичні засоби, призначені для усунення неприємних для людини запахів, викликаних потовиділенням, щуо запобігають виділенню поту.

У статті проведено аналіз композичійних складників дезодоруючих косметичних продуктів, які мають спільне призначення $i$ згідно з рекламою та етикеткою пакування виконують однакову дію на шкіру. Досліджено косметичні продукти, представлені на споживчому ринку Украӥни:

- Кремовий дезодорант-антиперспірант "Secret Key Platinum Power Delicate Antiperspirant Deodorant" (Cyclopentasiloxane, Aluminium Zirconium Tetrahlorydrex GLY, Dimethicone, Tribehenin, C18-36 Acid Trigliceride, Parfum, Hexyl Cinnamal, Hydroxycitronellal, Linalool, Limonene, Benzyl Salicylate, Geraniol, Citronellol - склад, зазначений на пакуванні) - дорожчий косметичний продукт.

- Дезодорант-стік «Защита от запаха и влаги. Чистая Линия» (Cyclopentasiloxane, Aluminium Zirconium Tetrahlorydrex GLY, Stearyl Alcohol, C12-C15 Alkyl Benzoate, PPG-14 Butyl Ether, Hydrogenerated Castor Oil, Parfum, Dimethicone, Polyethylene, Helianthus Annuus Seed Oil, Savlia Officinalis Leaf Extract, Steateth-100, BTH, Tocopheryl Acetate, Propylene Gglycol, Sorbitol, Citric Acid, Hexyl Cinnamal, Limonene, Linalool - склад, зазначений на пакуванні) - дешевший косметичний продукт.

Спільними композиційними складниками дезодоруючих косметичних продуктів є Cyclopentasiloxane, Aluminium Zirconium Tetrahlorydrex GLY, Dimethicone, Hexyl Cinnamal, Limonene, Linalool.

За аналізом композиційних складників досліджених дезодоруючих продуктів у них виявлено не дуже корисні компоненти (бензил саліцилат, диметикон, ліналоол, поліетилен, гексил ичннамал, стеариловий спирт, гідроксицитронеллаль), небезпечні для алергіків та людей з чутливою шкірою.

Аналіз більшої частини складників досліджених дезодоруючих косметичних продуктів показав, щзо їх компоненти, які відповідають за виконання функиії дезодоранту, є ідентичними. Солі алюмінію - «діюча речовина» в обох косметичних продуктах. Усі інші складники додані з метою покращення зовнішнього вигляду та споживчих властивостей засобів. Косметичний продукт «Чиста лінія» містить більше речовин, які доглядають за шкірою (рослинні олії, екстракт шавлії, вітамін Е), але водночас має токсичний наповнювач - поліетилен. Обидва засоби випускаються у стіках, більш дорожчий засіб має кремову текстуру. Запах досліджених засобів приємний. «Чиста лінія» обіияе 48 годин захисту, але наші дослідження, як споживачів, спростовують ие твердження виробника. Взикку його використовувати краще, адже з більш інтенсивним потовиділенням він праџює гірше. Якісніше свою функиіональну дію виконує антиперспірант "Secret Key Platinum Power Delicate Antiperspirant Deodorant".

За органолептичними випробуваннями досліджені дезодоруючі косметичні продукти можна рекомендувати до використання, проте вони не рекомендовані для викорнистання алергіками та людьми з чутливою шкірою.

Ключові слова: дезодоруючі косметичні продукти, антиперспіранти, порівняльна характеристика, якість, композииійні складники, органолептичні випробування. 
Постановка проблеми. На споживчому ринку України сьогодні представлено досить широкий асортимент дезодоруючих косметичних продуктів, антиперспірантів. Аналіз композиційних складників та визначення органолептичних показників таких засобів $€$ важливим етапом під час загального оцінювання їх якості та безпечності використання.

Аналіз останніх досліджень і публікацій. Оцінювання якості та безпечності використання вітчизняних дезодоруючих косметичних продуктів, антиперспірантів та таких, що імпортуються в Україну, проводять за різними показниками $[1 ; 2]$. Особлива увага при цьому приділяється хімічним, мікробіологічним, токсикологічним і клінічним дослідженням. Оцінюють якість та безпечність використання косметичних продуктів різного призначення [3-10].

Постановка завдання. Зважаючи на широкий асортимент дезодоруючих косметичних продуктів, антиперспірантів, представлених на споживчому ринку України, аналіз композиційних складників, проведення органолептичних випробувань таких засобів $\epsilon$ необхідним завданням під час оцінювання та порівняння якості й безпечності їх використання.

Виклад основного матеріалу дослідження. Для дослідження дезодоруючих косметичних продуктів було відібрано антиперспіранти у вигляді олівця різної цінової категорії:

1) Кремовий дезодорант-антиперспірант "Secret Key Platinum Power Delicate Antiperspirant Deodorant" (КП 1) - дорожчий косметичний продукт.

Склад КП 1, зазначений на пакуванні: Cyclopentasiloxane, Aluminium Zirconium Tetrahlorydrex GLY, Dimethicone, Tribehenin, C18-36 Acid Trigliceride, Parfum, Hexyl Cinnamal, Hydroxycitronellal, Linalool, Limonene, Benzyl Salicylate, Geraniol, Citronellol.

2) Дезодорант-стік «Защита от запаха и влаги. Чистая Линия» (КП 2) - дешевший косметичний продукт.

Склад КП 2, зазначений на пакуванні: Cyclopentasiloxane, Aluminium Zirconium Tetrahlorydrex GLY, Stearyl Alcohol, C12-C15 Alkyl Benzoate, PPG-14 Butyl Ether, Hydrogenerated Castor Oil, Parfum, Dimethicone, Polyethylene, Helianthus Annuus Seed Oil, Savlia Officinalis Leaf Extract, Steateth-100, BTH, Tocopheryl Acetate, Propylene Gglycol, Sorbitol, Citric Acid, Hexyl Cinnamal, Limonene, Linalool.

Органолептичні випробування досліджуваних косметичних продуктів проводили відповідно до стандартизованих методик [1].
Характеристика основних композиційних складників досліджених косметичних продуктів наведена нижче.

Cyclopentasiloxane.<smiles>C[Si]1(C)O[Si](C)(C)O[Si](C)(C)O[Si](C)(C)O[Si](C)(C)O1</smiles>

Циклопентасилоксан - синтетичний полімер, леткий силікон низької в'язкості. Має циклічну структуру будови. Джерелом отримання циклопентасилоксану, як і більшості силіконів, є метанол та силіцій (IV) оксид. Шляхом складної хімічної реакції з них отримують дуже схожу на воду рідину, безбарвну, прозору, практично без запаху, не жирну, текучу. Компонент належить до силіконів, емульгаторів, кондиціонерів. Ефективний для будь-якого типу шкіри. Фактор небезпеки - низький [2]. Циклопентасилоксан є спеціальним інгредієнтом для приготування емульсій типу «вода в силіконі» і складніших - «вода в силіконі у воді» 3 високими естетичними параметрами. Дає стабільність силіконовим емульсіям, гнучкість під час виробництва та розробки косметичних рецетур. Переносник як полярних, так i неполярних інгредієнтів, особливо жиророзчинних, чутливих до води інгердієнтів, наприклад, вітамінів. Властивості циклопентасилоксану, що застосовуються під час виробництва дезодорантів, допомагають рівномірно розподілити по шкірі косметичний продукт, роблять жирні рослинні олії більш легкими, текучими і сприяють їх всмоктуванню в шкіру; за рахунок дрібних молекул легко розноситься по шкірі разом із кремом або олією, забезпечує легке ковзання, швидко випаровується і не створює плівки на шкірі; не вступає в реакції з іншими компонентами косметики, не окиснюється і має високу стабільність у засобі.

Застосування косметики 3 циклопентасилоксаном небажано для людей, які хворіють на бронхіальну астму, під час загострення алергії, однак у складі антиперспіранту як стіка цей компонент $\epsilon$ досить безпечним [2]. 
Aluminium Zirconium Tetrachlorohydrex GLY.

Алюміній-цирконій тетрахлоргідрексгліцін гігроскопічна сполука, що використовується в багатьох антиперспірантах. Характеризується в'яжучою дією, звужує пори шкіри і канали потових залоз, у результаті чого скорочується обсяг потовиділення. Безводний алюміній-цирконій тетрахлоргідрексгліцін має дві основні функції як антиперспірант. По-перше, алюміній утворює гель, який забиває велику кількість пор шкіри, що знижує потовиділення. По-друге, алюміній-цирконій тетрахлоргідрексгліцін вбирає той піт, виділення якого не було попереджено першою дією [2]. Припускають, що алюміній-цирконій тетрахлоргідрексгліцін не всмоктується через шкіру, так само легко, як й інші сполуки алюмінію, а отже, токсичний ефект від використання цієї речовини може бути нижчим, ніж під час використання інших сполук алюмінію. 3 потом алюміній-цирконій тетрахлоргідрексгліцін може залишати на одязі плями жовтуватого кольору. У натуральних дезодорантах його замінюють на алюмо-калієвий галун, молекула якого має негативний іонний заряд і проникати через клітинну мембрану не може. Отже, контакту з організмом немає. Без запаху, характеризується антибактеріальною дією, створюючи особливу плівку. Потовиділення при цьому не блокується. Протипоказань для його використання немає. Позбавлений будь-яких токсичних або алергічних властивостей [2].

Dimethicone.

Диметикон $є$ одним із найпопулярніших силіконів у косметиці. Це синтетичний полімер, призначений для пом'якшення шкіри, створення захисної плівки, що надає їй гладкість і шовковистість. Використовується в косметичних засобах як компонент, що покращує структуру та взаємосумісність різних інгредієнтів [8]. Має м'яку захисну дію на шкіру. Оптично прозорий, вважається інертним, нетоксичним компонентом. Проте забиває пори і не дає шкірі дихати. Диметикон, як й інші силікони, заборонені в натуральній та органічній косметиці, тому що, крім свого синтетичного походження, вони ще й забруднюють навколишнє середовище, не розкладаючись протягом довгих років [2].

Hexyl Cinnamal (Hexyl Cinnamaldehyde).

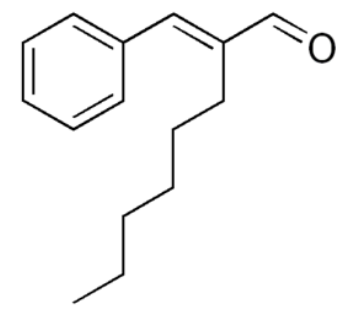

Гексил циннамал $\left(\mathrm{C}_{15} \mathrm{H}_{20} \mathrm{O}\right)$ - прозора рідина, колір від блідо-жовтого до жовтого. Надає косметичним продуктам запаху ромашки (в ефірному маслі ромашки його особливо багато). Не розчиняється у воді, але розчинний в оліях. С алергеном класу В (помірний алерген) [2]. Може викликати роздратування за концентрацій, які перевищують допустимі. Гексил циннамал ніде не заборонений, але його використання суворо регламентовано, що $\epsilon$ звичайною практикою для ароматизаторів [7; 8].

Linalool.<smiles>C=CC(C)(O)CCC=C(C)C</smiles>

Ліналоол $\quad$ (3,7-диметил-1,6-октадіен-3-ол) - речовина, що належить до групи терпенових спиртів. Особливість терпеноїдів, і зокрема ліналоола, в тому, що ці органічні сполуки часто зустрічаються в рослинах, беруть активну участь в обмінних процесах, але при цьому дуже мінливі та легко трансформуються під дією повітря, світла або водяної пари.

Ліналоол можна знайти в оліях, одержуваних iз багатьох видів рослин, при цьому ізомери ліналоола можуть характеризуватися різними квітковими ароматами, що робить ліналоол незамінним ароматизатором для парфумерної та косметичної промисловості. До того ж линалоол дуже дешевий і його легко виробляти. Швидко окиснюється під дією кисню і жирних кислот, при цьому утворюються хімічні сполуки, здатні викликати алергію. Антиоксиданти, що входять до складу косметики, уповільнюють окиснення ліналоола, але алергенні оксиди ліналоола все одно утворюються, якщо порушений температурний режим зберігання косметики або герметичність ії упаковки, а особливо якщо перевищено термін придатності. Може викликати алергію [2].

Limonene.<smiles>C=C(C)C1CC=C(C)CC1</smiles> 
Лимонен надає свіжий, легкий цитрусовий або хвойний аромат косметичним продуктам. Чудово розчиняє жири, а тому використовується у виробництві косметичних продуктів як нешкідлива альтернатива спиртам. Лимонен ефективно бореться 3 грибковими та бактеріальними мікроорганізмами, допомагає очищати шкіру і запобігає псуванню косметики. Це речовина, що належить до терпенових вуглеводнів.

Лимонен - популярна ароматична віддушка для косметики. Дослідження показали, що лимонен викликає алергію не частіше за інші ароматизатори, в тому числі натурального цитрусового походження [2].

Tribehenin.

Трибехенін - тригліцерид біхенової (С22) кислоти. Являє собою дуже м'який і аморфний віск, може бути використаний для зміни властивостей інших восків шляхом розм'якшення структури та зниження кристалічності й жорсткості. Забезпечує продуктам плавне нанесення і приємні відчуття.

C18-36 Acid Trigliceride.<smiles>CC(CC=O)CCCC(C)(C)O</smiles>

Синтетичний віск, схожий за властивостями на канделільский. Досить тугоплавкий. Надає високу жорсткість стікам. Абсолютно безпечний компонент [2].

Hydroxycitronellal.

Гідроксицитронеллаль - ароматизатор. Має свіжо-квітковий аромат. $€$ досить сильним алергеном [2].

Benzyl Salicylate.<smiles>O=C(OCc1ccccc1)c1ccccc1O</smiles>

Бензил саліцилат - речовина, внесена до списку речовин, здатних викликати алергічні реакції [2]. Ефір саліцилової кислоти. Характеризується слабким бальзамічним запахом і фіксуючими властивостями.
Stearyl Alcohol.

Стеариловий спирт. Жирний спирт, що використовується як пом'якшуючий компонент, емульгатор. Сприяє консервації інших інгредієнтів у складі косметичного засобу. $€$ безпечним, проте викликає алергію у разі індивідуальної чутливості [2].

C12-C15 Alkyl benzoate.

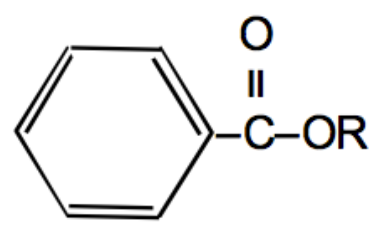

Абсолютно безпечний компонент під час використання за призначенням. Це суміш синтетичних спиртів. Виконує роль емульгатора, загущувача. Може використовуватися як розчинник, фіксатор аромату, знижує відчуття жирності засобу [7].

PPG-14 Butyl Ether.

Бутиловий Ефір Поліпропілен гліколь-14. Використовується як корисна добавка до косметичних композиційних складів. Емолент, розроблений для твердих стіків. Не залишає плям. Може використовуватися для зниження липкості [8].

За аналізом більшої частини складників досліджених дезодоруючих продуктів, наявні у них компоненти, які відповідають за виконання функції дезодоранту, є ідентичними. Солі алюмінію - «діюча речовина» в обох косметичних продуктах. Усі інші складники додані з метою покращення зовнішного вигляду та споживчих властивостей засобів. «Чиста лінія» містить більше речовин, що доглядають за шкірою (рослинні олії, екстракт шавлії, вітамін Е), але водночас має токсичний наповнювач, поліетилен [2]. Обидва продукти випускаються у стіках, проте більш дорожчий засіб має кремову текстуру. Запах досліджених косметичних продуктів приємний. «Чиста лінія» обіцяє 48 годин захисту, але наші дослідження, як споживачів, спростовують це твердження виробника. Взимку його використовувати краще, адже з більш інтенсивним потовиділенням він працює гірше. Якісніше свою функціональну дію виконує антиперспірант "Secret Key Platinum Power Delicate Antiperspirant Deodorant".

Таким чином, результати органолептичних випробувань засобів КП 1 і КП 2 можна вважати задовільними [1]. Спільні композиційні складники дезодоруючих косметичних продуктів - Cyclopentasiloxane, Aluminium Zirconium Tetrahlorydrex GLY, Dimethicone, Hexyl Cinnamal, Limonene, Linalool. 
Висновки. За аналізом композиційних складників досліджених дезодоруючих косметичних продуктів, представлених на споживчому ринку України, у них виявлено не дуже корисні компоненти (бензил саліцилат, диметикон, ліналоол, поліетилен, гексил циннамал, стеариловий спирт, гідроксицитронеллаль), небезпечні для алергіків та людей з чутливою шкірою.

Встановлено, що за органолептичними випробуваннями дезодоруючі косметичні продукти можна рекомендувати до використання, проте не бажано алергикам та людям з чутливою шкірою.

\section{Список літератури:}

1. ДСТУ 5009:2008. Вироби парфумерно-косметичні. Правила приймання, відбирання проб, методи органолептичних випробувань. Київ, 2009. Держспоживстандарт України. 4 с.

2. Суворов А.В. Справочник по клинической токсикологии. Нижний Новгород : Изд-во НГМА, 1996. $180 \mathrm{c}$.

3. Вишнікіна О.В., Лихолат О.А. Хімічна експертиза якості косметичних засобів, що імпортуються в Україну. Вісник Академії митної служби України. Серія: Технічні науки. 2009. № 1. С. 55-62.

4. Хребтань О.Б., Кучинська А.М. Дослідження якості та безпечності косметичних кремів для рук. Вісник Чернігівського державного технологічного ун-ту. Серія: Технічні науки. 2012. № 3 (59). С. $55-62$.

5. Прокопенко В.П., Кіркова М.С. Дослідження хімічного складу косметичних засобів. Імідж сучасного педагога. 2013. № 6. С. 35-36.

6. Пилипенко Т.М., Чигиринець О.Е., Воробйова В.І., Єфімова В.Г. Дослідження фізико-хімічних показників якості піномийних косметичних засобів. Технічні науки та технології. 2016. № 1 (3). С. 222-228.

7. Пилипенко Т.М., Рябчун Ю.В., Єфімова В.Г. Дослідження якості косметичних кремів для рук. Технічні науки та технології. 2017. № 4 (10). С. 210-216.

8. Єфімова В.Г., Пилипенко Т.М., Нікора О.В., Невпряга П.Ю. Розробка рецептури емульсійного косметичного продукту на основі колоїдних закономірностей. Технічні науки та технологї̈. 2018. № 1 (11). C. $178-187$.

9. Шендерова Е.С., Толкачева Т.А., Фомичева Н.С. Изучение содержания и стабильности флавоноидов в экстрактах из листьев одуванчика лекарственного. Сборник трудов конференции «Достижения фундаментальной, клиничекской медицьнны и фармации». Витебск, 23-24 января 2019. С. 268-270.

10. Пилипенко Т.М., Єфімова В.Г., Денисюк І.В. Дослідження фізико-хімічних характеристик косметичних рідин для обличчя. Вчені записки Таврійського наиіонального університету імені В.І. Вернадського. Серія «Технічні науки». 2019. Том 30 (69). № 4. Частина 2. С. 67-71.

\section{Pylypenko T.M., Yefimova V.G., Kuzmenko A.B. COMPARATIVE CHARACTERIZATION AND ASSESSMENT OF THE QUALITY OF DEODORIZING COSMETIC PRODUCTS}

Deodorizing cosmetic products, antiperspirants - cosmetic products designed to eliminate unpleasant odors caused by sweating and to prevent sweat.

The article analyzes the composition components of deodorizing cosmetic products that have a common purpose and the same effect on the skin according to the advertising and packaging label. The following cosmetic products presented on the consumer market of Ukraine have been researched:

- Cream deodorant-antiperspirant "Secret Key Platinum Power Delicate Antiperspirant Deodorant" (Cyclopentasiloxane, Aluminium Zirconium Tetrahlorydrex GLY, Dimethicone, Tribehenin, C18-36 Acid Trigliceride, Parfum, Hexyl Cinnamal, Hydroxycitronellal, Linalool, Limonene, Benzyl Salicylate, Geraniol, Citronellol - the composition indicated on the label) - the cosmetic product with a higher price.

- Deodorant stick "Protection against odor and moisture. Clean Line" (Cyclopentasiloxane, Aluminium Zirconium Tetrahlorydrex GLY, Stearyl Alcohol, C12-C15 Alkyl Benzoate, PPG-14 Butyl Ether, Hydrogenerated Castor Oil, Parfum, Dimethicone, Polyethylene, Helianthus Annuus Seed Oil, Savlia Officinalis Leaf Extract, Steateth-100, BTH, Tocopheryl Acetate, Propylene Gglycol, Sorbitol, Citric Acid, Hexyl Cinnamal, Limonene, Linalool - the composition indicated on the label) - the cosmetic product with lower price.

Common components of both cosmetic products are Cyclopentasiloxane, Aluminium Zirconium Tetrahlorydrex GLY, Dimethicone, Hexyl Cinnamal, Limonene, Linalool.

The analysis of the composition of previously mentioned deodorizing products revealed not very useful components (benzyl salicylate, dimethicone, linalool, polyethylene, hexyl cinnamal, stearyl alcohol, hydroxycitronellal), which are dangerous for people with allergies and sensitive skin.

The analysis of the composition of chosen products showed that the components responsible for deodorizing functions are identical for both cosmetic products. Aluminum salts are the "active ingredient" in both cosmetic products. The rest of the components were added to enhance the appearance and consumption properties of the products. The "Clean Line" cosmetic product contains more skincare products (vegetable oils, sage extract, 
vitamin E), but at the same time has a toxic polyethylene filler. Both deodorants are produced as sticks, but the more expensive product has a creamy texture. The odor of both cosmetic products is pleasant. "Clean Line" promises 48 hours of protection, but our consumers research disproves this manufacturer's statement. It is better to use this product in the winter because it doesn't work well with more intensive sweating. The antiperspirant "Secret Key Platinum Power Delicate Antiperspirant Deodorant" performs its functional effect better.

Organoleptic tests proved that both deodorant cosmetic products can be recommended for use, but are not recommended for people with allergies and sensitive skin.

Key words: deodorizing cosmetic products, antiperspirants, comparative characterization, quality, compositional components, organoleptic tests. 